\title{
EVALUATION OF THE RISK OF DIFFUSE POLLUTION OF GROUNDWATER BY NITROGEN SUBSTANCES FROM AGRICULTURAL LAND USE AS BACKGROUND FOR ALLOCATION OF EFFECTIVE MEASURES
}

\author{
RADOSLAV BUJNOVSKÝ ${ }^{1}$ PETER MALÍK², JAROMÍR ŠVASTA²
}

${ }^{1}$ Water Research Institute, Nábr. arm. gen. L. Svobodu 5, 81249 Bratislava, Slovak Republic; e-mail: bujnovsky@vuvh.sk ${ }^{2}$ State Geological Institute of Dionýz Štúr, Mlynská dolina 1, 81704 Bratislava 11, Slovak Republic; e-mail: peter. malik@geology.sk; jaromir.svasta@geology.sk

\begin{abstract}
Bujnovský R., Malík P., Švasta J.: Evaluation of the risk of diffuse pollution of groundwater by nitrogen substances from agricultural land use as background for allocation of effective measures. Ekológia (Bratislava), Vol. 35, No. 1, p. 66-77, 2015.

The risk of diffuse pollution of groundwater by nitrogen substances from agricultural land is perceived as a result of the interaction of groundwater vulnerability (determined by the characteristics of the environment overlying groundwater in relation to water transport or soil solution) and loading of overlying environment by nitrogen. Index of groundwater vulnerability was assessed on the basis of four parameters, namely, the amount of effective rainfall in the period from October to March, the capacity of soil to accumulate water, the average depth of the groundwater table and the permeability of the rock environment. Assessment of the index of loading of overlying environment by nitrogen was based on two parameters, namely, nitrogen balance and crop cover on agricultural land in the winter half on districts level in 2012, which corresponds with current state of the load. The resulting risk of groundwater pollution by nitrogen was expressed by the formula counting with the transformed values of groundwater vulnerability index and the index of loading of overlying environment by nitrogen. From practical point of view, the above mentioned indexes, as well as the subsequent risk of diffuse groundwater pollution, were spatially expressed via three associated categories. Based on the evaluation of relevant parameters, $5.18 \%$ of agricultural land falls into the category of very high and high risk, $42.20 \%$ in the medium risk category and $52.62 \%$ in the category of low and very low risk of diffuse pollution of groundwater by nitrogen from agricultural land.
\end{abstract}

Key words: groundwater, vulnerability, environment load, agricultural land use, risk of pollution, nitrogen.

\section{Introduction}

Diffuse pollution from agriculture, which often has intensive character, is considered as a major cause of the insufficient water quality currently observed in many parts of Europe, contributing $50-80 \%$ of the total nitrogen load and about half of the total phosphorus load on Europe's freshwaters (Dworak et al., 2010; EEA, 2012; OECD, 2012). The situation may be different in smaller catchments with high population densities (e.g. large cities), insufficient 
wastewater treatment or many industrial facilities discharging poorly treated wastewater.

Understanding the main causes leading to the occurrence of an excessive pollution of groundwater (with respect to nitrogen substances) is the key to an effective solution of the mentioned problem. The starting point for solving this problem is to identify areas that significantly contribute to current water status. Environmental risk assessment, through which it is possible to identify these areas, is based on the concept of 'source of pollution $\rightarrow$ transport path $\rightarrow$ receptor (part of the environment and/or human health)' (Daly et al., 2002; Malík, Švasta, 2004; Windolf et al., 2012), which, given the particular type and origin of contamination, may be interpreted as nutrient load environment $\rightarrow$ transport nutrients in the environment $\rightarrow$ receptor. The specific vulnerability of groundwater in groundwater body (hydrogeological structure) represents a more 'environmentalist' thinking on groundwater protection, as it seeks to provide below-limit concentrations of specific substances across the aquifer. This way of risk evaluation is presented.

In relation to the pollution of groundwater with nitrogen, the risk is considered as a result of interaction of vulnerability, determined by the nature of the environment relevant to transport of nitrogen, and nitrogen $(\mathrm{N})$ load to overlying environment as a result of agricultural land use. The specific type of risk, immediately related to agriculture land use, is a risk of nitrogen leaching from (the root layer of) soil, whilst the amount of washed nitrogen in various forms (mainly nitrates, nitrites marginally) usually does not correspond to the amount of nitrogen entering into groundwater (e.g. Schaffer, Delgado, 2002).

\section{Material and methods}

Groundwater pollution by nitrogen (especially nitrates) is caused by its leaching, which is a function of the amount of rainfall exceeding water retention capacity of the soil, especially in the winter half and the amount of residual nitrogen in the soil at the end of the growing season (e.g. ADAS, 2007; De Jong et al., 2007; Haberle et al., 2009). The risk assessment of groundwater pollution with nitrogen is based on indexing the parameters of overlying media, which are denoted by the term vulnerability (with respect to groundwater), and parameters of the load of the overlying environment by nitrogen called also as hazard, which arises as a consequence of land management. This comes with a choice of available parameters of environment and land management. The description of method for assessing the risk of diffuse pollution of groundwater by nitrogen is a part of the next chapter.

\section{Results and discussion}

\section{Groundwater vulnerability}

The vulnerability of groundwater was expressed by groundwater vulnerability index (iZPzV) and the following formula (1):

$$
\mathrm{iZPzV}=\mathrm{EZ} \times \mathrm{KPAV}+\mathrm{HPV} \times \mathrm{PHP}
$$

where

$\mathrm{iZPzV}$ is the groundwater vulnerability index,

$\mathrm{EZ}$ is the amount of effective rainfall in the period October to March (in mm), KPAV is the soil capacity to accumulate water (in mm) (Bujnovský et al., 2009), 
HPV is the average depth of groundwater table level under the land surface (in m), PHP is the permeability of the rock environment, expressed by hydraulic conductivity (in $\mathrm{m} \cdot \mathrm{s}^{-1}$ ).

The amount of effective rainfall in the period October to March was expressed as unevaporated precipitation, summarised for respective period after being calculated on monthly basis (Švasta, Malík, 2006), as well as effective rainfall in winter half of the year. Spatial information on the average depth of groundwater table level under the land surface were taken from Malík et al. (2012) and permeability of the rock environment was based on the results by Malík et al. (2007).

Table 1. Rating of environmental parameters.

\begin{tabular}{|c|c|c|}
\hline \multirow{2}{*}{$\begin{array}{l}\text { Parameter } \\
\text { Effective rainfall (EZ) X. - III. }\end{array}$} & \multicolumn{2}{|c|}{ Value } \\
\hline & $<100 \mathrm{~mm}$ & 1 \\
\hline & $101-150 \mathrm{~mm}$ & 2 \\
\hline & $151-200 \mathrm{~mm}$ & 3 \\
\hline & $201-250 \mathrm{~mm}$ & 4 \\
\hline & $>250 \mathrm{~mm}$ & 5 \\
\hline \multirow[t]{5}{*}{ Soil capacity to accumulate water (KAPV) } & $<100 \mathrm{~mm}$ & 1.0 \\
\hline & $101-200 \mathrm{~mm}$ & 0.8 \\
\hline & $201-300 \mathrm{~mm}$ & 0.6 \\
\hline & $301-400 \mathrm{~mm}$ & 0.4 \\
\hline & $>400 \mathrm{~mm}$ & 0.2 \\
\hline \multirow[t]{5}{*}{ Depth of groundwater table level under the land surface (HPV) } & $<1.5 \mathrm{~m}$ & 5 \\
\hline & $1.6-3.0 \mathrm{~m}$ & 4 \\
\hline & $3.1-5.0 \mathrm{~m}$ & 3 \\
\hline & $5.1-10.0 \mathrm{~m}$ & 2 \\
\hline & $>10 \mathrm{~m}$ & 1 \\
\hline \multirow{5}{*}{$\begin{array}{l}\text { Permeability of the rock environment/hydraulic conductivity } \\
\text { (PHP) }\end{array}$} & $<1 \cdot 10^{-6} \mathrm{~m} \cdot \mathrm{s}^{-1}$ & 0.2 \\
\hline & $1 \cdot 10^{-6}$ to $1 \cdot 10^{-5} \mathrm{~m} \cdot \mathrm{s}^{-1}$ & 0.4 \\
\hline & $1 \cdot 10^{-5}$ to $1 \cdot 10^{-4} \mathrm{~m} \cdot \mathrm{s}^{-1}$ & 0.6 \\
\hline & $1 \cdot 10^{-4}$ to $1.10^{-3} \mathrm{~m} \cdot \mathrm{s}^{-1}$ & 0.8 \\
\hline & $>1.10^{-3} \mathrm{~m} \cdot \mathrm{s}^{-1}$ & 1.0 \\
\hline
\end{tabular}

The scores of individual parameters of environment that enter into the calculation of groundwater vulnerability index (iZPzV) are reported in Table 1.

Index of groundwater vulnerability by nitrates from agricultural land use is rated at five levels, and to each one, calculated and transformed value is assigned (Table 2).

From practical point of view, groundwater vulnerability index was spatially expressed via three associated categories - very low and low, medium and high and very high (Fig. 1). Based on the evaluation, $3.32 \%$ of agricultural land of the Slovak Republic falls into the category of very high and high vulnerability, $32.34 \%$ into the medium vulnerability category and $64.34 \%$ into the category of low and very low vulnerability. 
Table 2. Categorisation of the values of groundwater vulnerability index (iZPzV).

\begin{tabular}{|l|c|c|}
\hline Groundwater vulnerability level & Calculated iZPzV values & Transformed iZPzV values (th iZPzV) \\
\hline Very low & $<2.32$ & 1 \\
\hline Low & $2.33-4.24$ & 2 \\
\hline Medium & $4.25-6.16$ & 3 \\
\hline High & $6.17-8.08$ & 4 \\
\hline Very high & $>8.08$ & 5 \\
\hline
\end{tabular}

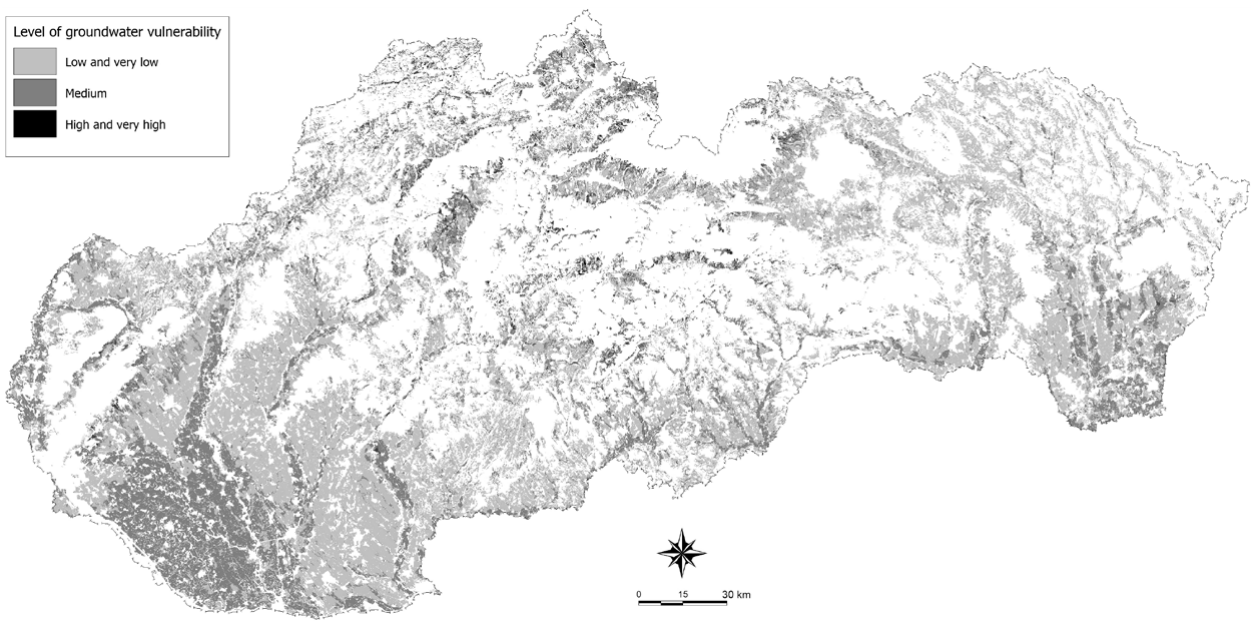

Fig. 1. The spatial distribution of associated categories of groundwater vulnerability.

\section{Load of overlying environment (agricultural land) by nitrogen}

Assessment of the load of overlying environment by nitrogen was based on nitrogen balance (BN) and crop cover on agricultural land in the winter half (RK) on districts level in 2012, which corresponds with current state of the load. This year was selected, as it belongs to those in which at national level, higher $\mathrm{N}$ surplus caused also by lower uptake influenced by weather course as well as by the higher $\mathrm{N}$ consumption in fertilizers since 1991 was observed. The scores of individual parameters of land management that enter into the calculation of the corresponding index (iZNPD) is reported in Table 3.

Whilst nitrogen balance is a certain estimate of residual nitrogen in the soil, crop cover in the autumn-spring period is a factor that can significantly affect the amount of nitrogen leaching losses (e.g. Dabney et al., 2001; Lacroix et al., 2005). Nitrogen leaching in the conditions of Central Europe is particularly important in the autumn-spring period (e.g. Haberle et al., 2009; Buczko, Kuchenbuch, 2010).

The load of overlying environment by nitrogen was expressed by the index (iZNPD) and the following formula: 
Table 3. Rating of parameters of agricultural land management.

\begin{tabular}{|c|c|c|}
\hline Parameter & \multicolumn{2}{|l|}{ Value } \\
\hline \multirow[t]{5}{*}{ Nitrogen balance (BN) } & $<20.0 \mathrm{~kg} \mathrm{~N} \cdot \mathrm{ha}^{-1} \cdot$ year $^{-1}$ & 1 \\
\hline & $20.1-40.0 \mathrm{~kg} \mathrm{~N} \cdot \mathrm{ha}^{-1} \cdot \mathrm{year}^{-1}$ & 2 \\
\hline & $40.1-60.0 \mathrm{~kg} \mathrm{~N} \cdot \mathrm{ha}^{-1} \cdot$ year $^{-1}$ & 3 \\
\hline & $60.1-80.0 \mathrm{~kg} \mathrm{~N} \cdot \mathrm{ha}^{-1} \cdot$ year $^{-1}$ & 4 \\
\hline & $>80.0 \mathrm{~kg} \mathrm{~N} \cdot \mathrm{ha}^{-1} \cdot$ year $^{-1}$ & 5 \\
\hline \multirow{5}{*}{$\begin{array}{l}\text { Crop cover on agricultural land in the winter half with } \\
\text { regard to nitrogen uptake capacity (RK) }\end{array}$} & $<20 \%$ & 1.0 \\
\hline & $21-40 \%$ & 0.8 \\
\hline & $41-60 \%$ & 0.6 \\
\hline & $61-80 \%$ & 0.4 \\
\hline & $>80 \%$ & 0.2 \\
\hline
\end{tabular}

$$
\mathrm{iZNPD}=\mathrm{BN} \times \mathrm{RK}
$$

where

iZNPD is the load of overlying environment by nitrogen,

$\mathrm{BN}$ is the nitrogen balance (calculated by OECD, 2007) (in $\mathrm{kg} \mathrm{N} \mathrm{ha}^{-1}$ year $^{-1}$ ), RK is the crop cover on agricultural land in autumn-spring period (in \%).

Information on fertilizer $\mathrm{N}$ consumption was obtained from the Central Control and Testing Institute for Agriculture (ÚKSÚP), and information on crop production and animal stocks by districts was obtained from Statistical office of the Slovak Republic.

Index of the load of environment by nitrogen was rated at five levels, and to each one, calculated and transformed value was assigned (Table 4).

Table 4. Rating of index expressing overlying environment load by nitrogen (iZNPD).

\begin{tabular}{|l|c|c|}
\hline $\begin{array}{l}\text { Level of overlying environment load by } \\
\text { nitrogen }\end{array}$ & Calculated iZNPD values & $\begin{array}{c}\text { Transformed iZNPD values } \\
\text { (th iZNPD) }\end{array}$ \\
\hline Very low & $<1.16$ & 1 \\
\hline Low & $1.17-2.12$ & 2 \\
\hline Medium & $2.13-3.08$ & 3 \\
\hline High & $3.09-4.04$ & 4 \\
\hline Very high & $>4.04$ & 5 \\
\hline
\end{tabular}

Spatial distribution of the index of overlying environment load by nitrogen, similarly as in the case of previous index, was expressed via three associated categories - very low and low, medium and high and very high (Fig. 2). Based on the evaluation, 25.07\% of agricultural land falls into the category of very high and high load, $14.63 \%$ to medium load category and $60.30 \%$ into the category of low and very low load by nitrogen. 


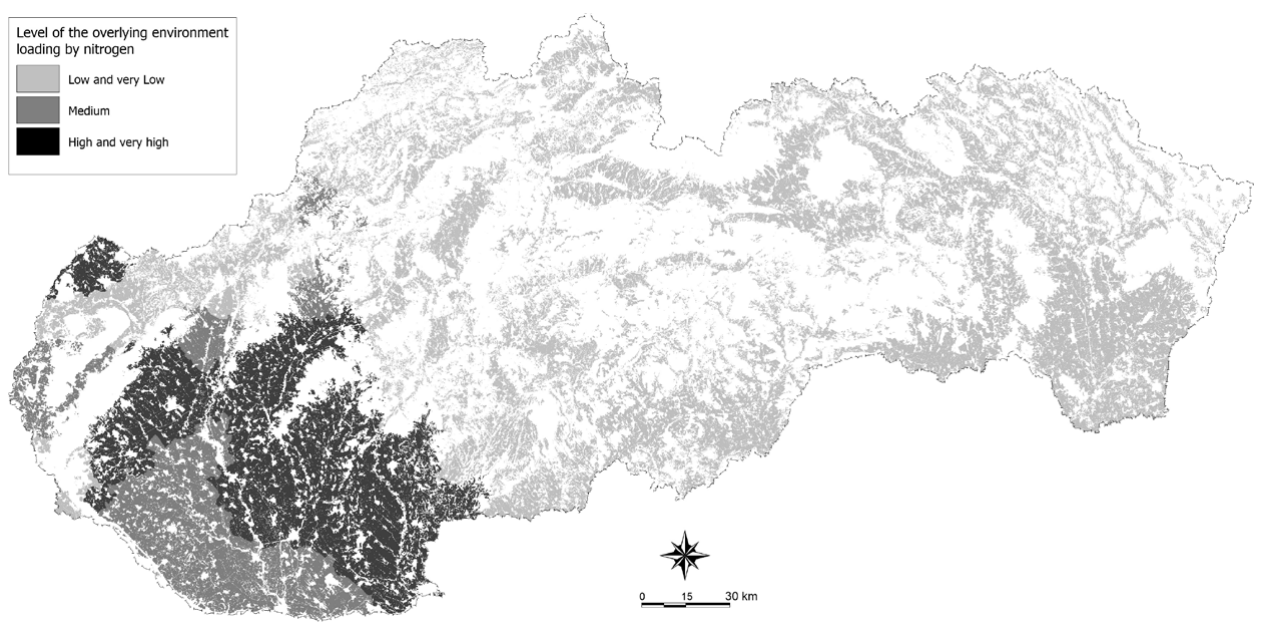

Fig. 2. The spatial distribution of the associated categories of environmental load by nitrogen.

Table 5. Categorisation of the values of risk of groundwater pollution by nitrogen.

\begin{tabular}{|l|c|}
\hline Level of risk of groundwater pollution by nitrogen & RZPzV values \\
\hline Very low & $<2.0$ \\
\hline Low & $2.1-4.0$ \\
\hline Medium & $4.1-6.0$ \\
\hline High & $6.1-8.1$ \\
\hline Very high & $>8.1$ \\
\hline
\end{tabular}

Risk of groundwater diffuse pollution by nitrogen (RZPzV)

The risk of groundwater pollution with nitrogen was expressed by the formula into which enter the transformed values of groundwater vulnerability index and index of loading of overlying environment by nitrogen, ranging within levels one to five (Equation 3). In fact, this procedure represents the application of the evaluation matrix, which in such type of assessment is used (Wrightson et al., 2008):

$$
\mathrm{RZPzV}=\text { th } \mathrm{iZPzV}+\text { th iZNPD }
$$

Risk of groundwater diffuse pollution by nitrogen, with classification criteria stated in Table 5, was spatially expressed through the associated three risk categories (Fig. 3). Based on the evaluation, $5.18 \%$ of agricultural land falls into the category of very high and high risk, $42.20 \%$ in the medium risk category and $52.62 \%$ in the category of low and very low risk of diffuse pollution of groundwater by nitrogen from agricultural land. 


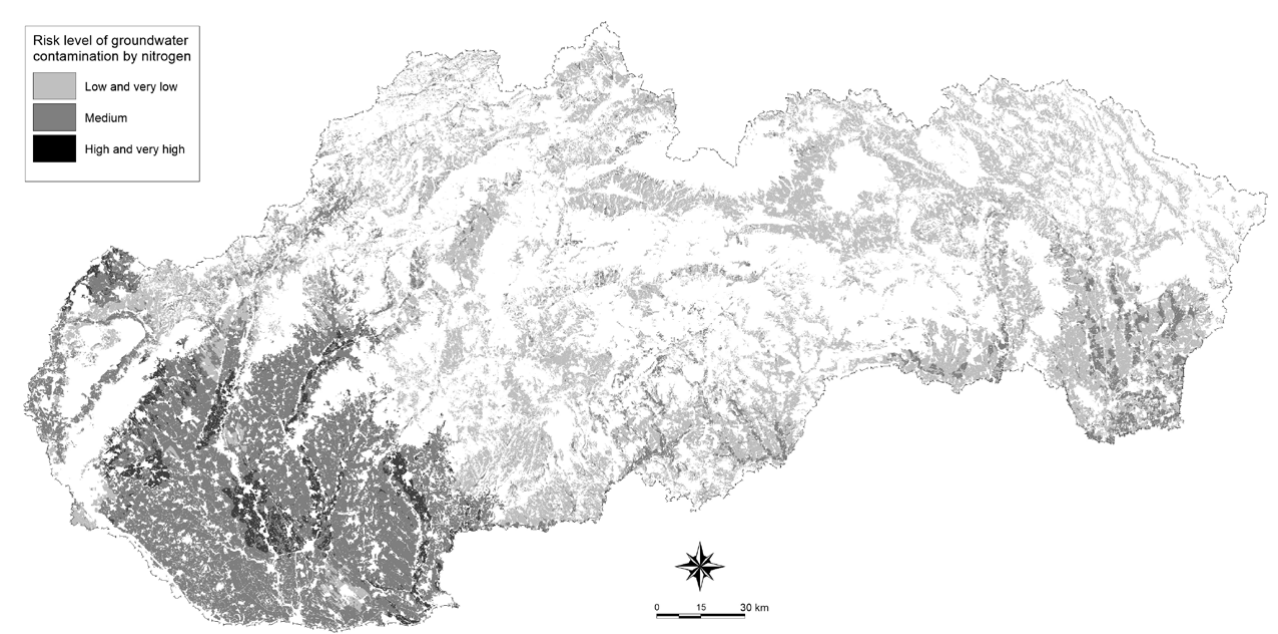

Fig. 3. The spatial distribution of the associated categories of the risk of groundwater diffuse pollution by nitrogen from agricultural land use.

The above values and spatial distribution of risk of groundwater pollution by nitrogen substances are somewhat distorted by the index values of the overlying environment load by nitrogen, which is processed from available data at district level. More precise results of the risk of groundwater pollution by nitrogen from the use of agricultural land can be achieved via using more detail data on nitrogen consumption and cropping structure, which can be obtained only from specific farms.

Index methods, in combination with the overlaid maps within the GIS, are an important group of various methods that find use in the groundwater vulnerability as well as the particular risk assessment (National Research Council, 1993; Burkart et al., 1999; Gogu, Dassargues, 2000; Voigt et al., 2004; Berkhoff, 2008). Kerr-Upal et al. (1999) have used analogical approach of a risk assessment for groundwater contamination by nitrates, as mentioned earlier in this paper, according to which the risk is a result of evaluation of the properties of the soil environment and land use patterns together with nitrogen load. The risk assessment resulting from the fertilizer application in Slovakia (Holubec et al., 2005) was based on the amount of $\mathrm{N}$ applied per year and subsequent scoring of these values with regard to the limits of $\mathrm{N}$ rates in defined vulnerable areas and degree of vulnerability. Such approach does not consider other nitrogen sources as well as the excess of nitrogen in autumn, which is subject to leaching in winter half, as referred by Haberle et al. (2009). Consumption of commercial fertilizers and animal manure is frequently used as the indicator of environment load by nitrogen. A more objective indicator of real load is nitrogen balance, which is usually interpreted in relation to the potential leaching risks of this nutrient (e.g. Halberg et al., 2005; Sieling, Kage, 2006; Bujnovský, 2014).

The term vulnerability is frequently used in connection with the implementation of the Nitrate Directive in vulnerable zones but with different meaning as these are defined by the nitrates content in groundwater (Ondrejková et al., 2012). Defined vulnerable areas also include areas where the nitrate content in groundwater exceeds the concentration limits. It is 
necessary to mention that the risk of groundwater pollution by nitrates from agriculture is justified only where the nitrate concentration has not exceeded the value $50 \mathrm{mg} \cdot \mathrm{l}^{-1}$. Otherwise the risk of over limit contamination is actually filled and in view of this substance is achieved insufficient state of groundwater.

\section{The need to take effective measures}

As the current trend of nitrates decreasing at EU level seems relatively slow to reach the level of water quality comparable at least good ecological status in 2027, it implies that additional measures are needed to reduce diffuse pollution, which can be implemented through River Basin Management Plans within Water Framework Directive (WFD) and through full compliance with the Nitrates Directive (Solheim et al., 2012). It creates pressure on extension of Nitrate Directive vulnerable zones and apprises the need of updating the relevant Action Programs and incorporating the WFD requirements to cross-compliance - management requirements for the provision of agricultural support schemes in respect of decoupled direct payments.

Understanding the main causes leading to groundwater pollution and achieving the required improvement represents complex problem and the assessment of the risk of diffuse pollution of groundwater by nitrogen is important part of the whole picture as illustrated in Fig. 4.

WFD environmental objectives for groundwater concerning quality include preventing the deterioration of groundwater bodies, as well as reversal of significant sustained upward trend in the concentration of a pollutant that is caused by human activity with the aim of progressively reducing groundwater pollution.

Diffuse groundwater pollution by nitrates can be caused by current as well as past activities. Reversing the unfavourable state of water (in our case above, the threshold concentration of nitrates in groundwater) to reach the target state (up to $50 \mathrm{mg} \mathrm{L}^{-1}$ ) is a process that is not fully controlled by changes in agricultural activities in short period. As follows from a number of publications (e.g. Schilling, Wolter, 2007; Meals et al., 2010; Windolf et al., 2012), time for responding groundwater body/zone to the effects of measures at restoring the groundwater quality varies from a few years to decades and consists of the time needed to create the necessary effect in practice, the time required for expression of the effect on the level of the ground water level and the time required for water body/zone in response to the effect of measures. Amongst these, the last one is usually the longest. As follows from the results of an evaluation using the model MONERIS (Vernohr, 2012), the residence time of nitrates in groundwater within the international Danube river basin in Slovakia ranges from 5 to 50 years. This time lag is a key reason why some groundwater bodies may not achieve good status by 2015 or later even if all necessary measures are implemented soon by Member States (Solheim et al., 2012).

The basic problem of reducing the diffuse water pollution from agriculture, especially by nitrates, consists mainly in reducing the surplus of applied $\mathrm{N}$ with regard to its off-take by crops that is possible to reach through balanced fertilisation (total amount of N, P rate) and timing. It corresponds with key principle - improvement of the $\mathrm{N}$ efficiency by tightening 
Risk of over-limit pollution of groundwater by nitrogen based on environment load and vulnerability assessment

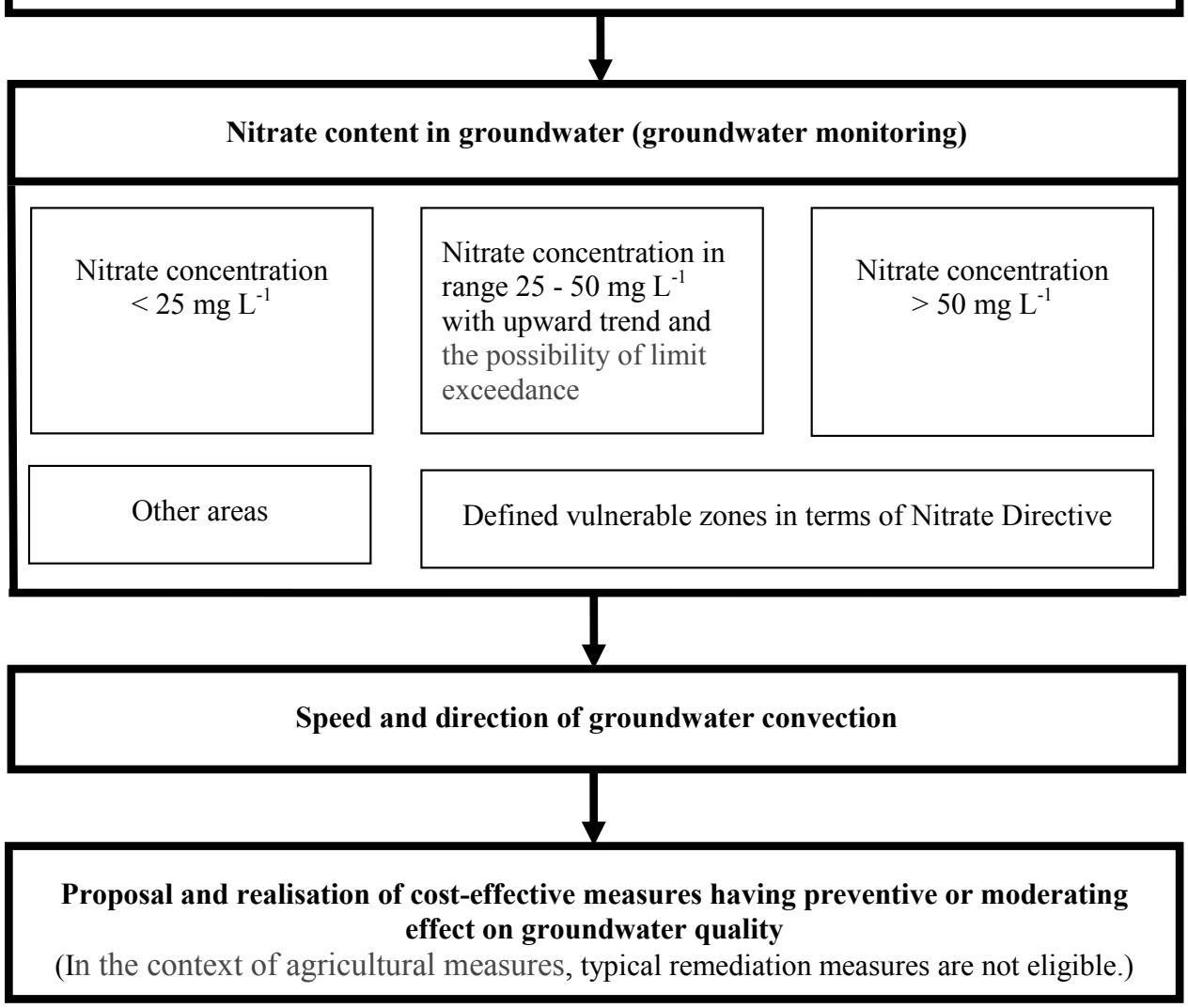

Fig. 4. The risk of diffuse groundwater pollution by nitrogen from the use of agricultural land in relation to draft measures to maintain or improve the water status.

the $\mathrm{N}$ cycle as highlighted by Webb et al. (2010). Just the timing of $\mathrm{N}$ fertilizers and animal manures (especially the liquid ones) can significantly contribute to the minimisation of $\mathrm{N}$ loses through leaching without negative impact on crop productivity (that should be in relation to soil productivity potential of given site). As introduced by Torstensson et al. (2006), key problem at the application of animal manure is the insufficient synchronicity between mineralisation of organic $\mathrm{N}$ and its uptake by crop. In line with above mentioned, nitrogen from organic manures, animal ones inclusive, is less manageable than fertilizer $\mathrm{N}$ that is immediately available for root system of crops. Also covering of soil by winter crops, perennial crops as well as winter catch crops is not insignificant (e.g. Dabney et al., 2001; Lacroix et al., 2005). It is necessary to pay attention also to $\mathrm{N}$ loses from insufficient storage capacities for 
animal manures (e.g. ALTERRA, 2007, 2008). Above mentioned information was reflected at definition of types of measures relevant for Slovak conditions (Bujnovský, 2014).

More precise identification of the current sources of pollution, taking into account the character of pollution, is indispensable precondition of setting up the therapy or prevention through target-oriented and efficient measures. Any re-assessment of adopted measures in agriculture related to water protection against pollution presupposes especially the clarification of the scale of the challenge from agricultural pressures and the determination of the efficiency of the adopted measures. As introduced by Schröder and Neeteson (2008), without scientific insight in the causes of success and failure, there is a risk of focusing on the wrong aspects.

In view of the above, the decisive basis for the selection and subsequent implementation of effective measures in agriculture represent information about the risk of groundwater pollution by nitrates in response to residence time of nitrates in groundwater and the status and development trend of nitrate concentration in groundwater.

\section{Conclusion}

Understanding the main causes leading to the occurrence of an excessive pollution of groundwater is the key to an effective solution of the mentioned problem. The starting point for solving this problem is to identify areas that significantly contribute to current water status via risk assessment.

The risk of diffuse pollution of groundwater by nitrogen from agricultural land is perceived as a result of the interaction of vulnerability (determined by the characteristics of the environment overlying groundwater in relation to the water transport or soil solution) and loading of overlying environment by nitrogen.

Based on the evaluation, $5.18 \%$ of agricultural land of selected sub-basin falls into the category of very high and high risk, $42.20 \%$ in the medium risk category and $52.62 \%$ in the category of low and very low risk of diffuse pollution of groundwater by nitrogen from agricultural land.

With regard to complexity of the given problem, there are considerable reserves and assessment of the risk of diffuse pollution of groundwater by nitrogen is important part of the whole picture. So, decisive basis for the selection and subsequent implementation of effective measures in agriculture represent information about the risk of groundwater pollution by nitrates in response to residence time of nitrates in groundwater and the status and development trend of nitrate concentration in groundwater.

\section{References}

ADAS (2007). Diffuse nitrate pollution from agriculture - strategies for reducing nitrate leaching. ADAS report to DEFRA - supporting paper D3 for the consultation on implementation of the Nitrates Directive in England. Pendeford: ADAS.

ALTERRA (2007). Assessment of the designation of Nitrate vulnerable zones in Poland. Report within Contract for Outsourcing of technical and administrative assistance: 2006/441164/MAR/B1. Wageningen: ALTERRA.

ALTERRA (2008). Assessment of the designation of Nitrate vulnerable zones in Slovakia. Report within Contract for Outsourcing of technical and administrative assistance: 2007/474674/MAR/B1. Wageningen: ALTERRA. 
Berkhoff, K. (2008). Spatially explicit groundwater vulnerability assessment to support the implementation of the Water Framework Directive - a practical approach with stakeholders. Hydrology and Earth Systems Science, 12, 111-122. DOI: 10.5194/hess-12-111-2008.

Buczko, U. \& Kuchenbuch R.O. (2010). Environmental indicators to assess the risk of diffuse nitrogen loses from agriculture. Environ. Manag., 45, 1201-1222. DOI: 10.1007/s00267-010-9448-8.

Bujnovský, R., Balkovič, J., Barančíková, G., Makovníková, J. \& Vilček J. (2009). Evaluation and pricing of ecological functions of Slovak agricultural soils (in Slovak). Bratislava: VÚPOP.

Bujnovský, R. (2014). Nitrogen balance and measure in relation to the reduction of diffuse groundwater pollution with nitrogen from agriculture (in Slovak). Vodohospodársky Spravodajca, 57(11-12), 4-7.

Burkart, M.R., Kolpin, D.W. \& James D.E. (1999). Assessing groundwater vulnerability to agrochemical contamination in the Midwest US. Water Sci. Technol., 39(3), 103-112.

Dabney, S.M., Delgado, J.A. \& Reeves D.W. (2001). Using winter cover crops to improve soil and water quality. Commun. Soil Sci. Plant Anal., 32(7-8), 1221-1250. DOI: 10.1081/CSS-100104110.

Daly, D., Dassargues, A., Drew, D., Dunne, S., Goldschneider, N., Neale, S., Popescu, CH. \& Zwahlen F. (2002). Main concepts of the "European Approach" for karst groundwater vulnerability assessment and mapping. Hydrogeology Journal, 10(2), 340-345. DOI: 10.1007/s10040-001-0185-1.

De Jong, R., Yang, J.Y., Drury, C.F., Huffman, E.C., Kirkwood, V. \& Yang X.M. (2007). The indicator of risk of water contamination by nitrate-nitrogen. Can. J. Soil Sci., 87 (Special Issue), 179-188. DOI: 10.4141/S06-060.

Dworak, T., Berglund, M., Thaler, T., Fabik, E., Ribeiro, M.M., Laaser, C., Matauschek. M., Amand, B. \& Grandmougin B. (2010). Assessment of agriculture measures included in the draft River Basin Management Plans. Summary Report. Berlin/Vienna: Ecologic Institute.

EEA (2012). European waters - assessment of status and pressures. EEA Report No. 8/2012. Copenhagen: EEA.

Gogu, R.C. \& Dassargues A. (2000). Current trends and future challenges in groundwater assessment index using overlay and index methods. Environ. Geol., 39(6), 549-559. DOI: 10.1007/s002540050466.

Haberle, J., Kusá, H., Svoboda, P. \& Klír K. (2009). The changes of soil mineral nitrogen observed on farms between autumn and spring and modelled with simple leaching equation. Soil and Water Research, 4(4), 159-167.

Halberg, N., Verschuur, G. \& Goodlass G. (2005). Farm level environmental indicators: are they useful? An overview of green accounting systems for European farms. Agric. Ecosyst. Environ., 105, 195-212. DOI: 10.1016/j. agee.2004.04.003.

Holubec, M., Slivková, K., Kútnik, P. \& Kollár M. (2005). Assessment of pollution sources to protect water resources and the determination the protection zones (in Slovak). In Voda Zlín 2005 (pp. 121-125). Sborník príspěvků IX. mezinárodní vodohospodářské konference. Zlín: Zlínská vodárenská, a.s.

Kerr-Upal, M., Van Seters, T., Whitehead, G., Price, J. \& Stone M. (1999). Assessing the risk of groundwater nitrate contamination in the region of Waterloo, Ontario. Canadian Water Resources Journal, 24(3), 225-233. DOI: $10.4296 /$ cwrj2403225.

Lacroix, A., Beaudoin, N. \& Makowski D. (2005). Agricultural water nonpoint pollution control under uncertainty and climate variability. Ecological Economics, 53(1), 115-127. DOI: 10.1016/j.ecolecon.2004.11.001.

Malík, P. \& Švasta J. (2004). „European approach“ in the groundwater vulnerability assessment (in Slovak). Podzemná Voda, 10(1), 50-59.

Malík, P., Bačová, N., Hronček, S., Ivanič, B., Káčer, Š., Kočický, D., Maglay, J., Marsina, K., Ondrášik, M., Šefčík, P., Černák, R., Švasta, J. \& Lexa J. (2007). Zostavovanie geologických máp v mierke 1: 50000 pre potreby integrovaného manažmentu krajiny. Arch. No. 88158. Bratislava: ŠGÚDŠ.

Malík, P., Švasta, J., Bahnová, N., Kočický, D., Ivanič, B., Maretta, M., Špilárová, I. \& Zvara I. (2012). Komplexná geologická informačná báza pre potreby ochrany prírody a manažmentu krajiny (GIB-GES). Geologické Práce, $119,7-19$.

Meals, D.W., Dressing, S.A. \& Davenport T.E. (2010). Lag time in water quality response to best management practices: A review. J. Environ. Qual., 39, 85-96. DOI: 10.2134/jeq2009.0108.

National Research Council (1993). Ground water vulnerability assessment. Contamination potential under conditions of uncertainty. Washington, D.C.: National Academy Press.

OECD (2007). OECD and EUROSTAT gross nitrogen balances handbook. Paris: OECD.

OECD (2012). Water quality and agriculture. Meeting the policy challenge. Paris: OECD publishing.

Ondrejková, I., Májovská, A., Gergelová, Z., Mrafková, L., Palušová, Z., Luptáková, A., Bujnovský, R., Supeková, M., Grófová, R. \& Kuníková E. (2012). Report on the implementation Council Directive 91/676/EEC concerning the protection against pollution caused by nitrates from agricultural sources in Slovakia (in Slovak). Bratislava: MŽP SR. 
Schafffer, M.J. \& Delgado J.A. (2002). Essentials of a national nitrate leaching index assessment tool. Journal of Soil and Water Conservation, 7(6), 327-335.

Schilling, K.E. \& Wolter C.F. (2007). A GIS-based groundwater travel time model to evaluate stream nitrate concentration reductions from land use change. Environ. Geol., 53, 433-443. DOI: 10.1007/s00254-007-0659-0.

Schröder, J.J. \& Neeteson J.J. (2008). Nutrient management regulations in the Netherlands. Geoderma, 144(3-4), 418-425. DOI: 10.1016/j.geoderma.2007.12.012.

Sieling, K. \& Kage H. (2006). N balance as an indicator of $\mathrm{N}$ leaching in an oilseed rape - winter wheat - winter barley rotation. Agric. Ecosyst. Environ., 115, 261-269. DOI: 10.1016/j.agee.2006.01.011.

Solheim, A.L., Austnes, K., Kristensen, P., Peterlin, M., Kodeš, V., Collins, R., Semerádová, S., Künitzer, A., Filippi, R., Prchalová, H., Spiteri, C. \& Prins Th. (2012). Ecological and chemical status and pressures in European waters. Thematic assessment for EEA Water 2012 Report. Prague: European Topic Centre on Inland, Coastal and Marine Waters.

Švasta, J. \& Malík P. (2006). Priestorové rozloženie priemerných efektívnych zrážok na území Slovenska. Podzemná Voda, 12(1), 65-77.

Torstensson, G., Aronnoson, H. \& Bergström L. (2006). Nutrient use efficiencies and leaching of organic and conventional cropping systems in Sweden. Agron. J., 98(3), 603-615. DOI: 10.2134/agronj2005.0224.

Vernohr, M. (2012). Background paper on recent methods, input data and modelled nutrient emissions and potential of measures to reduce these in the Danube catchment. Paper presented on the ICPDR workshop November 5-6th 2012, Bucharest.

Voigt, H-J., Heinkele, Th., Jahnke, Ch. \& Wolter R. (2004). Characterization of groundwater vulnerability to fulfill requirements of the water framework directive of the European Union. Geofísica Internacional, 43(4), 567-574.

Webb, J., Sørensen, P., Velthof, G., Amon, B., Pinto, M., Rodhe, L., Salomon, E., Hutchings, N., Burczyk, P. \& Reid J. (2010). Study on variation of manure $N$ efficiency throughout Europe. A report for European Commission Directorate General Environment. Didcot: AEA Technology plc.

Windolf, J., Blicher-Mazhiesen, G., Carstensen, J. \& Kronvang B. (2012). Changes in nitrogen loads to estuaries following implementation of governmental action plans in Denmark: A paired catchment and estuary approach for analysing regional responses. Environmental Science and Policy, 24, 24-33. DOI: 10.1016/j.envsci.2012.08.009.

Wrightson, I., Cooper, S., Crookes, M., Grundy, C.L., King, N., Larner, J., Lewis, P., Lohmann, D.H., Maxwell, C., Perry, D., Sanderson, D.M. \& Lipworth S. (2008). Environment, Health and Safety Committee Note on: Environmental risk assessment. London: RSC. 